\title{
Decomposing the Determinants of Interest Rates in Turkey and Selected: Emerging Markets Implementing Inflation Targeting Policies
}

\author{
Erhan Aslanoğlu \\ Piri Reis University \\ Pinar Deniz \\ Marmara University
}

Follow this and additional works at: https://ecommons.luc.edu/meea

Part of the Economics Commons

\section{Recommended Citation}

Aslanoğlu, Erhan and Deniz, Pinar, "Decomposing the Determinants of Interest Rates in Turkey and Selected: Emerging Markets Implementing Inflation Targeting Policies". Topics in Middle Eastern and North African Economies, electronic journal, 18, 1, Middle East Economic Association and Loyola University Chicago, 2016, http://www.luc.edu/orgs/meea/

This Article is brought to you for free and open access by the Journals and Magazines at Loyola eCommons. It has been accepted for inclusion in Topics in Middle Eastern and North African Economies by an authorized administrator of Loyola eCommons. For more information, please contact ecommons@luc.edu.

\section{(c) (7) (2)}

This work is licensed under a Creative Commons Attribution-Noncommercial-No Derivative Works 3.0 License. (C) 2016 the authors 


\section{Decomposing the Determinants of Interest Rates in}

Turkey and Selected: Emerging Markets Implementing Inflation Targeting Policies

Erhan Aslanoğlu*

Pınar Deniz ${ }^{\dagger}$

JEL Classification: C32, E52,E58

Keywords: Inflation Targeting, Emerging Countries, Structural VAR

\footnotetext{
* Piri Reis University, Department of Economics and Finance, E-mail: easlanoglu@ pirireis.edu.tr
}

${ }^{\dagger}$ Marmara University, EU Institute, E-mail: pinar.deniz@marmara.edu.tr 


\begin{abstract}
Inflation Targeting (IT) is a monetary policy in which keeping inflation as close as to the target level using policy tools is the main focus for many central banks. However, purely targeting inflation has the potential to reveal the drawback of the trade-off between inflation and output, leaving out the possibility of perfectly anticipated inflation where there is no trade-off. IT policy is relatively more difficult for emerging market economies compared to developed countries due to the potential fragilities emerging from the large amount of fluctuations in the portfolio investments. High current account deficits, fiscal dominance, lack of credibility, imperfections in many goods markets, volatility in commodity prices are some of the factors that contribute to the fragilities in the economic stabilities and render the economy more open to external shocks. Overall, lack of institutionalism in emerging economies may hamper central bank independence, which is essential for a fully-functioning IT regime. Under such conditions, giving priority to IT is a difficult path to follow together with the impacts of the developments in other economic variables at different horizons. Hence, decomposing the weights of the economic fundamentals in determining the monetary policy will provide information about devotion to IT as the policy rule.

Considering the domestic environment and the externalities, this paper aims (i) to investigate the monetary policy rule of the Central Bank of the Republic of Turkey under a structural VAR (vector auto-regression) model, (ii) to structurally decompose the variation of the determinants of the monetary policy, and (iii) examine the determinants and the decompositions for a set of inflation targeting emerging market economies. The IT (explicit or implicit) emerging economies to make comparison are as follows: Brazil, Chile, Mexico, Czech Republic, Hungary, Poland, Indonesia, South Korea, South Africa, and Israel. SVAR methodology is used for time series analysis for Turkey whereas GMM based panel VAR is employed for the panel of 11 emerging countries. Empirical findings suggest importance of institutional variables in monetary policy rules especially in the long run and that adopting IT and rise in credibility contributes to central banks of emerging economies by lowering interest rates.
\end{abstract}

\title{
1. Introduction
}

Inflation targeting (IT) policy is adopted by many countries following the pioneer, New Zealand by 1990, as the gains are observed through time. Bernanke and Mishkin (1997) explain that IT is characterized as announcement of a target for inflation, an increase in the communication 
with the public so as to share the policy objective, and generally a rise in the credibility of the central bank. However, governments often challenge with central banks to implement discretionary monetary policies especially in election periods. Central bank independence comes as a crucial term in here. An effective communication with public through announcements of "drawbacks of over-expansionist policies" may help central banks resist such pressures coming from the government side.

Even if the economic benefits of IT are significant, unwillingness to adopt the policy can be explained under two cases: (i) transition to inflation targeting policy requires some preparations in the form of improvements in the fiscal performance, financial system, credibility in the institutions, etc., and that the economy is not well-prepared to adopt IT policy, (ii) IT places inflation at the heart of monetary policies hampering direct interventions to the economic circumstances that contradicts IT.

A full and strict commitment to IT policy is simply placing inflation as the primary monetary policy and leaving all other indicators as subsidiary not only in the long run but also in the short run. However, practically, central banks do not implement such strict commitments and allows for missing target level in short horizons when economic conditions require other variables to be of primary concern. In fact, some supply side shocks, such as oil price shock, may lead to very costly results in the output level when IT policy is implemented strictly in the short or medium run. On the other hand, short run flexibilities should never hamper long run commitments to IT policy. There no clear sanctions for missing target level but such a fail will destroy the credibility of central banks which highly require credibility to stabilize the economic conditions due to domestic fragilities such as high current account deficits, lack of financial resources and hence requirement of foreign inflows which may generally be attributed to the "non-developed" world. Commitment to IT regime will help improve credibility of central banks and hence more gains can be obtained with less effort in the monetary policy. The importance of IT regime for developing economies is also highlighted in Walsh (2009). He explains that IT improved the macroeconomic performances for developing economies but the performances of IT and non-IT are relatively similar for developed economies.

The scope of this paper is on emerging economies (Turkey and the emerging country group that is similar to Turkey in economic characteristics), a highly debated country group that is characterized with high growth potential resulting from low quantity of capital and hence theoretically high marginal productivity, i.e., high returns to investment. Requirement of financial resources render them dependent on foreign inflows. Hence, these economies are 
generally in a competition to attract foreign investors. On the other hand, such openness creates fragilities in the way that abrupt portfolio outflows will have destructive consequences for the domestic economies. At this point, providing and managing credibility to the financial side of the economy is highly important so as to prevent capital outflows together with a panic environment.

There many studies investigating the effects of IT policy for emerging economies. Mishkin (2004), focusing on two emerging countries, Brazil and Chile, argues that that IT, even if it is a complicated issue for emerging economies, can be a very powerful tool to maintain macroeconomic stability, if applied properly. Lin and Ye (2009), using panel data analysis for 13 developing countries that adopt IT, observe that IT has significant impact on lowering inflation and variability in inflation rate. However, the effects are not homogeneous to each economy and that depends on country characteristics such as exchange rate movements, fiscal discipline and the willingness to meet preconditions before adopting the policy. Siregar and Goo (2010) investigate the effectiveness of IT policies adopted by two emerging economies, Indonesia and Thailand, during stable and turbulent years resulting from global economic conditions and examine the commitment to IT policy credibly. Using Markov-switching approach to examine the monetary policy rule for 1990-2008 period, they observe evidence of credible implementation of IT in both economies during stable and turbulent years. They also suggest that both economies have experienced a decline in inflation rates during the post-IT period. However, using a panel data analysis for developing countries, Brito and Bystedt (2010) do not find a significant impact of IT on inflation and output growth.

Monetary policies are standardized under Taylor rule model which formalize how central banks specify interest rate using inflation and output gap. The model can differ according to the monetary rule each central bank defines. Interest rate smoothing mechanism, i.e., lagged value of interest rates, changes in exchange rates are generally used in addition to the standardized model. On the other hand, several other economic variables can be included in the monetary rule function depending on the importance central bank gives. Central banks have short term interest rates as the monetary policy instruments. However, the real side of the economy is directly affected from the long run interest rates, which are determined in the market through expectations regarding long run and key interest rates only have indirect effects. The way to increase the power of the link between short run and long run interest rates is to increase the credibility of the central bank so that expectations are managed. There is no specific indicator to measure credibility but they can be proxied by governance/institutional variables 
since credibility is an institutional issue. Considering the importance of credibility for emerging market economies, it will be a more extensive analysis to include a governance variable to understand the policy decisions of these economies. Accordingly, Mishkin (2004) argues that institutional differences of emerging markets from advanced countries, such as weak fiscal institutions, weak financial institutions including government prudential regulation and supervision, low credibility of monetary institutions, should be taken into account to derive sound theory and policy advice. Similarly, Fraga et al. (2003) explains that IT contributes both to advanced and EM countries but it is more of a challenge for EMs due to their volatile macroeconomic environment and weaker institutions and credibility. Hence, it is important to consider institutional factors when analyzing monetary policy of EM economies.

The empirical literature on monetary policy rule, originating from Taylor (1993), is enormous, however the evidence on emerging economies is scarce. Empirical findings for emerging markets have mixed results. Frömmel et al. (2011) estimate monetary policy rules for six emerging Central and Eastern European (CEE) economies and find that some CEE countries explicitly switch from defending the peg to targeting inflation while other economies do not. Aizenman and Hutchison (2011) examine the role of real exchange rate and the distinction between commodity and non-commodity exporters under a Taylor rule model for a panel data of 16 emerging countries. They find clear evidence of a significant and stable response running from inflation to policy interest rates and that non-IT central banks place much less weight on inflation in setting interest rates. Teles and Zaidan (2010) evaluate the validity of Taylor rule principle for inflation control for 11 emerging countries using threshold unit root test and argue that if a Central Bank wants to stabilize inflation around the target, it should closely follow a long-term more than proportional reaction rule in relation to the expected inflation deviations. Sánchez-Fung (2011) examines whether Taylor-type reaction functions are practical for understanding how monetary authorities in Brazil behave following inflation targeting adoption and switching to a floating exchange rate regime. He finds that Brazilian Central Bank adjusts overnight interest rate (Selic) in line with the Taylor principle but it does not systematically react to exchange rate developments. Mehrotra and Sánchez-Fung (2011) estimate McCallum and Taylor monetary policy functions for 20 emerging market economies. Taylor monetary policy rule employs for inflation gap, output gap and change in nominal exchange rate, whereas McCallum model regresses monetary base on nominal income gap measure and change in nominal exchange rate. They find that the behavior of the IT economies are better captured with a hybrid McCallum-Taylor rule that regresses interest rates on nominal income gap measure 
and change in nominal exchange rate. Besides empirical side of the literature, Taylor-type of monetary policy rules are used as standard formula in papers that develop economic modeling such as New Keynesian DSGE models.

Turkey is the first country in MENA region adopting explicit IT regime. After decades of high inflation since late 1970s, Turkish economy experienced unprecedented decline in inflation rate after 4-year implicit inflation targeting regime (2002-2005) and reflected less volatile and fragile economic signs since the explicit inflation targeting regime of 2006. Until May 2010, policy rate was overnight interest rate. After that period, one-week repo became the main policy rate. After the February 2001 political and domestic crisis, crawling exchange rate peg regime adopted in 2000 was abandoned and Turkish currency was left to float. The new monetary policy is determined to be inflation targeting (IT) regime. An implicit form of IT regime was adopted until some economic conditions are satisfied. Public burden was a crucial obstacle to IT regime since risk premium due to default risk in high budget deficit economies put upward pressure on exchange rate and hence on inflation expectations. Hence, public issues are at the heart of the economic policy in order to accomplish an active monetary policy. Another impediment against properly working monetary policy is the uninformed and inexperienced public regarding the new monetary policy regime. Within the implicit IT period, fiscal reforms are implemented and communication facilities are prepared in order to achieve the targets.

Gürkaynak et al. (2015) examine the monetary policy in Turkey in the central bank independence period. Using monthly dataset for the period 2003-2014, they observe that there is a break in the Taylor rule model after 2010. Using 3 different Taylor rules (one includes inflation rate and \% deviation of IP from its trend, other one includes inflation rate and annual growth of IP, and the last one includes inflation rate, annual growth of IP and change in USD/TR rate), they assert that the impact of inflation on interest rate declines after 2009, suggesting that the attention Central Bank of Turkey pays declines after the break period.

The main objective of this paper is to decompose the weights of the economic fundamentals in determining the interest rates for Turkey and a panel of emerging economies implementing inflation targeting policy. The relevant empirical technique to apply is variance decomposition after the specification of the simultaneous equation system. VAR is a frequently used technique to obtain variance decomposition. However, there are several criticisms towards VAR models as no theoretical inference is included. In other words, every variable causes the other, such that all variables are endogenous. Such criticisms let to the development of structural 
VAR (SVAR) technique which is derived from standard VAR methodology and includes theoretical restrictions to the system so as to identify the model. After the theoretical identification regarding the variables in the simultaneous equation system is determined, short run and long run impulse response functions, variance decompositions and historical decompositions are obtained for Turkey. For panel dataset, impulse response functions, variance decompositions are obtained after the determination of panel VAR based on GMM methodology.

The rest of the paper is organized as follows. Section 2 briefly describes the methodology for SVAR and panel VAR analyses, presents a model of interest rate determination and explains the relevant data set. Section 3 is devoted to the empirical findings. Last section concludes the paper.

\section{Methodology}

\subsection{Time Series SVAR model}

The empirical analysis in this study is based on SVAR models proposed by Sims (1986), Bernanke (1986) and Blanchard and Watson (1986). In these models, parameters are estimated by imposing short run (contemporaneous) structural restrictions. An alternative methodology is developed by Shapiro and Watson (1988) and Blanchard and Quah (1989) imposing long run structural restrictions. Differently from standard VAR models, impulse response functions (IRF) and variance decompositions obtained from SVAR methodology have structural inferences.

The methodology for contemporaneous SVAR model is explained below. The standard VAR model for the variables in vectoral form $x_{t}$ is as follows.

(1) $A x_{t}=C(L) x_{t}+D \varepsilon_{t}$

Where $C(L)$ is the lag operator and $\varepsilon_{t}$ is the vector for unobservable variables, i.e., errors to the structural equations. Multiplying each side with $A^{-1}$, the reduced form of this system is obtained.

(2) $x_{t}=A^{-1} C(L) x_{t}+A^{-1} D \varepsilon_{t}$ 
$A^{-1} D \varepsilon_{t}$ is simply the residuals $\left(e_{t}\right)$ we obtain after running a standard VAR model given that the shocks have temporary effects, $\ell_{t}$ has white noise iid. process. If shocks have permanent effects, equation (2) will be written in first differences,

(3) $\Delta x_{t}=A^{-1} C(L) \Delta x_{1}+A^{-1} D \varepsilon_{t}$

Last term in equations (2) and (3) is the vector of residuals and $\varepsilon_{t}$ is the vector of structural shocks. If $A$ and $D$ are known, the dynamic structure of the model and structural shocks can be calculated from the coefficients of estimated standard VAR. Since these coefficient matrices are unknown, identification is attained by imposing theoretical restrictions. Thereby, the number of unknown structural parameters are to reduced to be less than or equal to the number of estimated parameters of the variance-covariance matrix of the VAR residuals (Keating, 1992). $n(n-1) / 2$ is the number of theoretical restrictions to achieve full identification where $\mathrm{n}$ is the number of variables in the model.

The methodology for long run SVAR model is explained below. Given the reduced form of this system of the standard VAR model in equation (2), some arrangements are applied.

$\left(I-A^{-1} C(L)\right) x_{t}=A^{-1} D \varepsilon_{t}$

(4) $x_{t}=\left(I-A^{-1} C(L)\right)^{-1} A^{-1} D \varepsilon_{t}$

Equation (4) shows how the structural shocks, $\varepsilon_{t}$, affect the long run levels of the variables in the model, i.e., $x_{t}=\left(I-A^{-1} C(L)\right)^{-1} A^{-1} D \varepsilon_{t}$ is simply the cumulative (long run) impact of the structural shocks.

Before SVAR model, stationarity of all variables are checked using Augmented Dickey Fuller (ADF) and Phillips-Perron (PP) unit root tests. Both tests have presence of unit root in the null hypothesis. After SVAR estimation, impulse response functions (IRFs) and variance decompositions (VARDECs) and historical decompositions are presented. IRFs give the effect of one time shock to an innovation on current and future values of the endogenous variables. VARDECs give the relative importance of each innovation in the variation of endogenous 
variables. Since the VAR model is estimated through a structural factorization, the IRF and VARDECs will be based on structural decomposition. Moreover, structural break analysis for the regression model is done using Bai and Perron (2003) with different approaches, namely as multiple breakpoint testing based on $L+1$ vs. $L$ sequentially determined breaks and 1 to $M$ globally determined breaks.

\subsection{Panel VAR model}

Panel VAR methodology is first proposed by Holtz-Eakin et al. (1988). Consider a homogenous panel VAR of order $p$ with panel-specific fixed effects as presented below.

$$
Y_{i t}=\sum_{j=1}^{p} A_{j} Y_{i t-j}+X_{i t} B+u_{i}+e_{i t}
$$

Where $Y_{i t}$ is a vector of endogenous variables, $X_{i t}$ vector of exogenous variables, and $u_{i}$ and $e_{i t}$ are vectors of panel fixed effects and idiosyncratic errors, successively. Using lagged dependent variable in the right-hand-side will lead to biasedness even with large number of cross sectional units. Generalized method of moments (GMM) technique will help obtain consistent estimates with small time period in dynamic panel analysis. In order to control for cross sectional heterogeneity, forward orthogonal deviation ${ }^{1}$ (Helmert transformation) is used which is suggested by Arellano and Bover (1995).

After system GMM panel VAR model based on the STATA routine provided by Love and Zicchino (2006), forecast error variance decompositions are also obtained using the STATA routine provided by Abrigo and Love (2015).

Before panel VAR test, the variables are checked whether they are stationary via panel unit root tests. Levin et al. (2002, LLC hereafter) is a panel unit root test with homogeneity assumption in the autoregressive coefficient, whereas Im et al. (2003, IPS hereafter) relaxes this assumption by allowing for heterogeneity. Both tests have presence of unit root in the null hypothesis.

\subsection{The model}

\footnotetext{
${ }^{1}$ Another method for removing fixed effects is mean-differencing which is commonly used. However, this method will lead to biased estimates.
} 
For the simultaneous equation system, we move from a basic Taylor rule where interest (INT) is determined by inflation (INF) and output gap (GAP). Output gap is positively defined, i.e., actual output minus potential output. In order to calculate output gap, we HP filtered ${ }^{2}$ natural logarithm of GDP. Enlarging the model, we incorporate change in exchange rate (XR) and an institutional variable (GOV) which may be a major concern for emerging markets as they are institutionally underdeveloped, in general. Moreover, in order to examine the impact of IT, we employ larger period rather than focusing on inflation targeting period. Therefore, inflation and inflation targeting dummy is employed rather than inflation gap. Besides IT dummy, dummy for economic crisis is also incorporated in the model.

Institutional variables, in simplistic form, reflect credibility of the institutions in the domestic economy. Domestic credibility and portfolio inflows, hence exchange rate are highly related for emerging countries. Due to the potential link between exchange rate and institutional variables that may cause multicollinearity problem, we use either of the two.

\subsubsection{SVAR model}

In the identification of the SVAR model, output gap is assumed to be most exogenous variable and interest rate is assumed to be completely endogenous. Exchange rate is restricted to be affected only from the output gap and inflation is restricted to be affected from output gap and exchange rate. This is referred as Model 1 in the study. Similarly, the model that includes institutional variable, which replaces exchange rate, is referred as Model 2. The identification is shown in matrix form from (5) to (7).

Model 1 (Model for GAP XR INF INT) for short run SVAR:

$$
\left(\begin{array}{l}
e_{t}^{G A P} \\
e_{t}^{X R} \\
e_{t}^{I N F} \\
e_{t}^{I N T}
\end{array}\right)=\left(\begin{array}{llll}
C(1) & & & \\
C(2) & C(3) & & \\
C(4) & C(5) & C(6) & \\
C(7) & C(8) & C(9) & C(10)
\end{array}\right) \cdot\left(\begin{array}{c}
\varepsilon_{t}^{G A P} \\
\varepsilon_{t}^{X R} \\
\varepsilon_{t}^{I N F} \\
\varepsilon_{t}^{I N T}
\end{array}\right)
$$

Model 2 (Model for GAP GOV INF INT) for short run:

\footnotetext{
${ }^{2}$ There are generally 3 different options to calculate output gap: (i) linear detrending, (2) nonlinear detrending via Hodrick-Prescott filter, (3) Kalman filtering. Hodrick-Prescott filter is the most common approach.
} 
(6) $\left(\begin{array}{l}e_{t}^{G A P} \\ e_{t}^{G O V} \\ e_{t}^{I N F} \\ e_{t}^{I N T}\end{array}\right)=\left(\begin{array}{llll}C(1) & & & \\ C(2) & C(3) & & \\ C(4) & C(5) & C(6) & \\ C(7) & C(8) & C(9) & C(10)\end{array}\right) \cdot\left(\begin{array}{c}\varepsilon_{t}^{G A P} \\ \varepsilon_{t}^{G O V} \\ \varepsilon_{t}^{I N F} \\ \varepsilon_{t}^{I N T}\end{array}\right)$

Model 1 and 2 for long run with the same order in variables:

(7) $C=\left(\begin{array}{cccc}C(1) & 0 & 0 & 0 \\ C(2) & C(5) & 0 & 0 \\ C(3) & C(6) & C(8) & 0 \\ C(4) & C(7) & C(9) & C(10)\end{array}\right)$

\subsubsection{PVAR model}

Models for panel VAR are defined as follows:

$$
I N T_{i, t}=\alpha+\beta_{1} I N F_{i, t}+\beta_{2} G A P_{i, t}+\beta_{3} X_{i, t}+\delta_{1} D_{\text {crisis } i, t}+\delta_{2} D_{\text {target } i, t}+e_{i, t}
$$

Where $X$ is a third factor from open economy side, i.e., , or from institutional side of the domestic economy, i.e., GOV. The PVAR regressions are again run under two models, i.e., Model 1 for GAP, XR, INF and INT; Model 2 for GAP, GOV, INF and INT.

\subsection{Dataset}

SVAR model is applied for Turkey using the quarterly dataset between 2003-2014. Institutional variables are announced annually. In the quarterly estimation for Turkey (due to lack of observation in annual dataset since institutional variables start by 1996), GOV is taken constant through the year. The dataset starts by 2003 since the economy is more stable compared to earlier periods.

GDP in constant domestic currency is HP filtered for output gap. Inflation data is annual CPI. Interest rate is interbank interest rate in end of period. Exchange rate is official nominal exchange rate per US dollar. Data set are obtained from OECD and World Bank databases. 
GDP and exchange rate are in logarithmic form. Annual dataset for the period of 1996-2014 for 11 other emerging economies, namely as Brazil, Chile, Czech Republic, Hungary, Indonesia, Israel, South Korea, Mexico, Poland, South Africa and Turkey are employed for panel VAR methodology.

Kaufmann et al. (2010) draw together data on perceptions of governance ${ }^{3}$ (institutions) from many sources, and define six dimensions of governance, namely as,

1. Voice and Accountability (VA)

2. Political Stability and Absence of Violence/Terrorism (POLSTAB)

3. Government Effectiveness (GOVEFF)

4. Regulatory Quality (REGQUA)

5. Rule of Law (RULELAW)

6. Control of Corruption (CC)

Out of all institutional variables POLSTAB, GOVEFF and REGQUA ${ }^{4}$ seem to be relevant to the governance linked with monetary policy. Kaufmann (2010, p.4) asserts that GOVEFF and REGQUA are related to "the capacity of the government to effectively formulate and implement sound policies" and POLSTAB is about politically motivated stability of government. The dataset on governance variables are available in World Governance Indicators (WGI) project ${ }^{5}$ financed by World Bank.

Using an earlier time period than the start of inflation targeting policy, IT dummy variable for emerging markets follow the dates given in Table 1. Table 2 provides descriptive statistics of all seven variables in panel data from for 11 emerging countries. Historical data for Turkey is given in Figure 1.

\footnotetext{
${ }^{3}$ Kaufmann et al. (2010, p. 4) defines VA, POLSTAB, GOVEFF, REGQUA, RULELAW and CC as follows: Capturing perceptions of the extent to which a country's citizens are able to participate in selecting their government, as well as freedom of expression, freedom of association, and a free media; Capturing perceptions of the likelihood that the government will be destabilized or overthrown by unconstitutional or violent means, including politically-motivated violence and terrorism; Capturing perceptions of the quality of public services, the quality of the civil service and the degree of its independence from political pressures, the quality of policy formulation and implementation, and the credibility of the government's commitment to such policies; Capturing perceptions of the ability of the government to formulate and implement sound policies and regulations that permit and promote private sector development; Capturing perceptions of the extent to which agents have confidence in and abide by the rules of society, and in particular the quality of contract enforcement, property rights, the police, and the courts, as well as the likelihood of crime and violence; Capturing perceptions of the extent to which public power is exercised for private gain, including both petty and grand forms of corruption, as well as "capture" of the state by elites and private interests.

${ }^{4}$ Saborowski and Weber (2013) suggest using regulatory quality as the determinant of interest rate as an institutional variable.

${ }^{5}$ The WGI database can be accessed by the following link:

http://info.worldbank.org/governance/wgi/index.aspx\#home, Accessed 18 December 2015.
} 
Topics in Middle Eastern and African Economies

Vol. 18, Issue No. 1, May 2016

Table 1: Inflation Targeting Adoption Dates for Emerging Markets

Country Inflation targeting adoption dates

\begin{tabular}{ll}
\hline Brazil & 1999 \\
Chile & 1999 \\
Czech Republic & 1997 \\
Hungary & 2001 \\
Indonesia & 2005 \\
Israel & 1997 \\
Korea, Republic of & 2001 \\
Mexico & 2001 \\
Poland & 1998 \\
South Africa & 2000 \\
Turkey & 2006 \\
\hline
\end{tabular}


Figure 1: Historical data for Turkey (2003Q1-2014Q4)

GAP

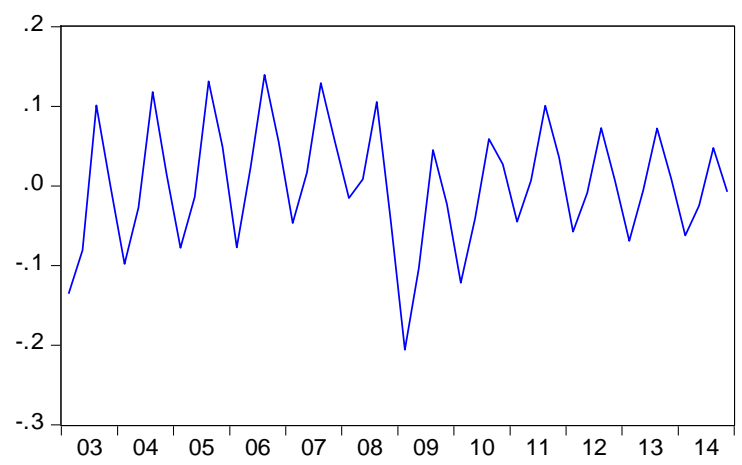

INF

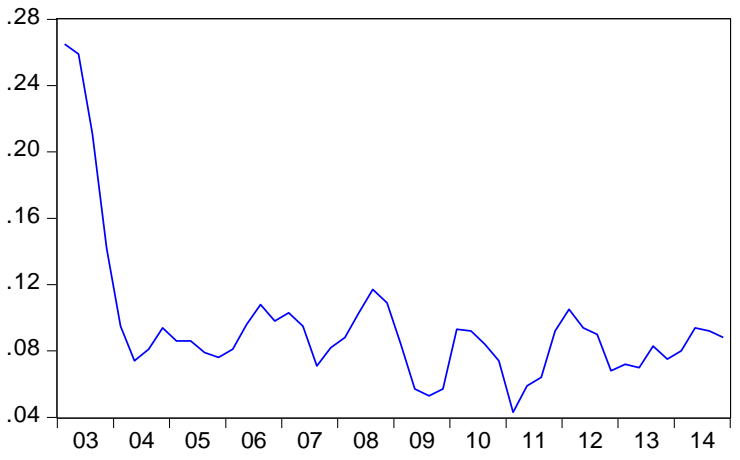

GOVEFF

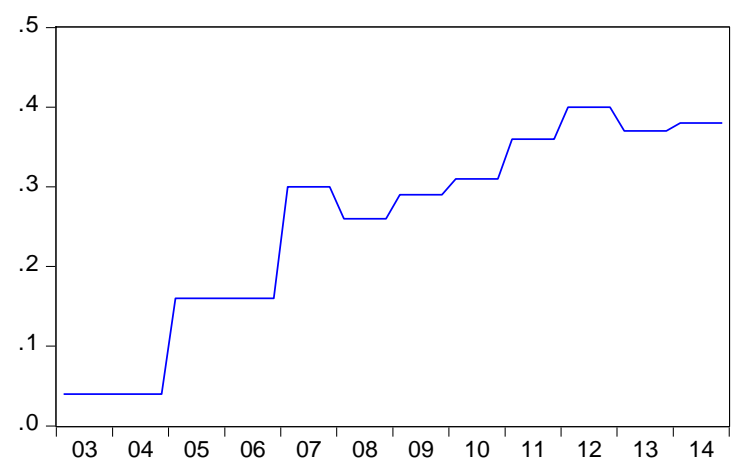

POLSTAB

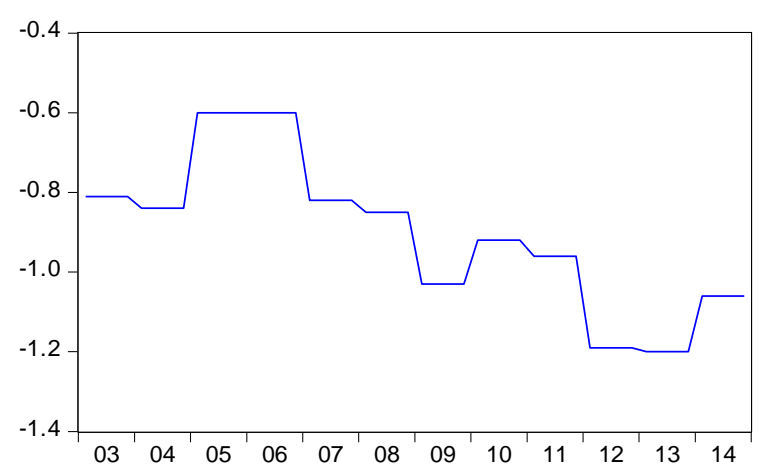

$\mathrm{XR}$



INT

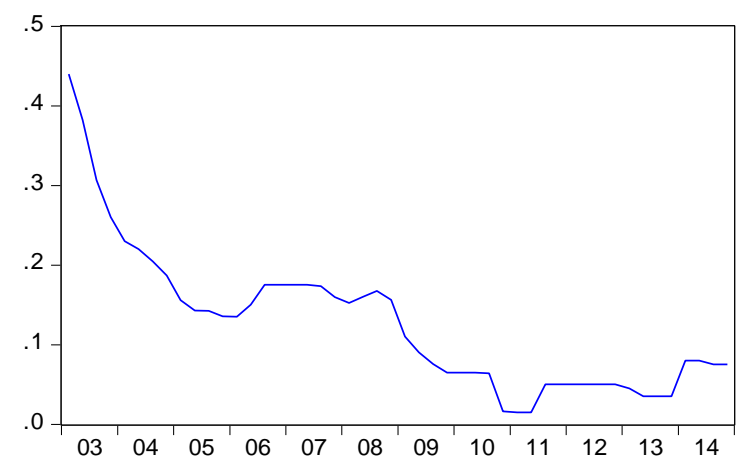

REGQUA

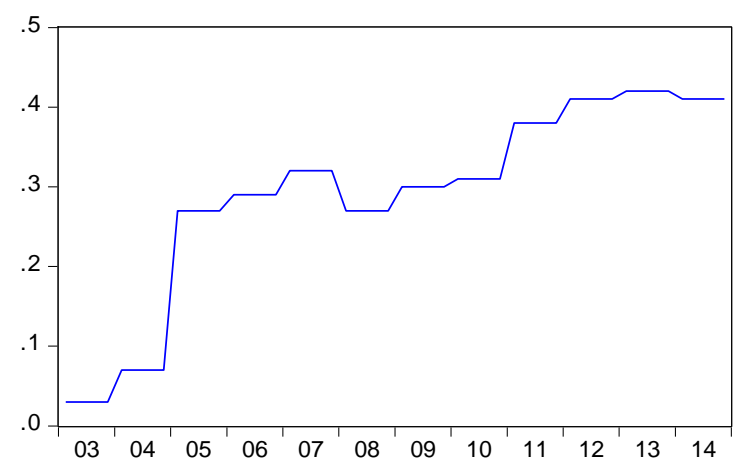


Table 2: Panel Dataset summary statistics

\begin{tabular}{cccccccc}
\hline & INT & INF & GAP & XR & REGQUA & POLSTAB & GOVEFF \\
\hline Mean & 0.115 & 0.081 & 0.000 & 3.491 & 0.658 & -0.103 & 0.551 \\
Median & 0.070 & 0.049 & 0.000 & 2.389 & 0.720 & -0.010 & 0.620 \\
Max. & 1.832 & 0.857 & 0.106 & 9.381 & 1.640 & 1.180 & 1.370 \\
Min. & 0.002 & -0.004 & -0.083 & -2.508 & -0.780 & -2.120 & -0.600 \\
Std. Dev. & 0.171 & 0.128 & 0.027 & 2.859 & 0.512 & 0.830 & 0.510 \\
Obs. & 209 & 209 & 209 & 209 & 209 & 209 & 209 \\
\hline
\end{tabular}

\section{Empirical Findings}

For panel VAR model, all three institutional variables are used whereas for SVAR for Turkey only REGQUA is employed as an institutional variable since it is observed to be the significant one.

\subsection{SVAR model}

Before SVAR model, all variables are tested using ADF and PP tests, given in Table 3, since SVAR is based on standard VAR model which is assumed to include stationary variables. Out of all, exchange rate and REGQUA have unit root. Hence, their first differences ${ }^{6}$ are used throughout the study. Crisis and IT dummies are used as exogenous variables in the structural model.

SVAR model for Turkey is analyzed under two models. Model 1, including GAP, XR, INF and INT, is based on VAR(2), i.e., optimal lag is selected as 2 using Schwarz information criterion. Model 2, including GAP, GOV, INF and INT, is based on VAR(3). Short run SVAR for Model 1 for Turkey, given in Table 4 and Figure 2, reflects that GAP and XR have positive and significant ${ }^{7}$ impact on INT, whereas INF is observed to be insignificant even in $10 \%$ significance level. Variance decomposition in Table 5 reflects that the variation in INT rate is explained by INT itself, with a ratio of around 70\%. XR and GAP are of second and third importance in affecting the variation in INT with $12 \%$ and $11 \%$ in horizon 1 , successively. However, the effect of XR increases as the horizon increases. Model 2 in long run, given in Table 6 and Figure 4, suggests that all variables have positive and significant effect on impact. Long run model brings information about cumulative effect of the sub-shocks. Variance

\footnotetext{
${ }^{6}$ Institutional variable is used in change form from previous year.

${ }^{7}$ Significant impacts on INT, which is the fourth equation, are shown with bold characters.
} 
decomposition for long run, in Table 7, reflects that the variation in INT is explained most by GAP of around $85 \%$ in horizon 1 . INF comes as of second importance with a proportion of around $14 \%$. As the horizon increases, the impact of GAP rises whereas impact of INF declines.

Short run SVAR for Model 2 for Turkey, given in Table 8 and Figure 6, reflects that only GAP is significant on impact. Variance decomposition, given in Table 9, suggests that the variation in INT is explained by itself with a proportion of around $91 \%$ in horizon 1 . However, the effects decline as the horizon increases. GAP is observed to be of second importance in horizon 1. However, the impact of INF increases sharply as the horizon increases. Model 2 in long run model, given in Table 10 and Figure 8, suggests that GAP and INF have significant and positive impact whereas REGQUA has negative and significant impact on INT. Variance decomposition for long run, in Table 11, reflects that the variation in INT is explained most by REGQUA and GAP and INF come as of second and third importance. However, the impact from GAP rises abruptly as the horizon increases and it becomes most important variable to explain the variation in INT after horizon 4, i.e., a year later.

Historical decompositions for long run given in Figures 5 and 9 suggest that the cumulative variation in INT between 2007-2009 period is explained strongly by GAP in both models, however long run historical decomposition for 2011-2014 period suggests that REGQUA dominates all in contributing to INT negatively and GAP comes second. All IRFs, i.e., Figures 2, 4, 6 and 8, eflect convergence to zero as the horizon increases which reveals that the system goes back to equilibrium. SVAR for Turkey suggests that the highest explanation comes from GAP and REGQUA in the long run whereas it is INT itself in the short run models. XR is almost of no importance in the long run and INF contributes slightly to the variation in INT in the long run. In the short run model, GAP again contributes positively to the variation in INT between 2007-2009 period. INF is almost of no importance in model 1 but in model 2, it dominates all (other than INT itself) after 2012 by contributing negatively to INT.

Models suggest that change in regulation quality has a negative and significant effect on interest rate in the long run. In other words, sound economic policies implemented by the government alleviate the burden on interest rates contributing to the confidence on the domestic economy. Output gap is observed to have a positive and significant effect on impact consistent to the literature. Change in exchange rate increases interest rate in the short run suggesting the pressure from foreign investors together with the highly open economic and financial structure of Turkey. Inflation reflects a positive and significant impact in the longer horizon. Lastly, 
interest rate is significantly affected from its past periods suggesting a smoothing mechanism in the monetary policy.

The regression model for Taylor rule is also tested for any potential breakpoint using Bai-Perron tests of multiple breakpoint tests, given in Table 13. For the test based on $L+1$ vs. $L$ sequentially determined breaks, breakdate obtained from the original sequential procedure and from repartition procedure is 2010Q1. Bai-Perron tests of 1 globally optimized breaks against the null of no structural breaks, along with the corresponding UDmax and WDmax test suggests 2010Q1 as the break date. The breakpoint for Taylor rule for Turkey is also consistent with the one obtained in Gürkaynak et al. (2015), which is 2010:01, using Chow test for monthly data between 2003-2014. However, there is no significant change in variance decompositions between the periods.

\subsection{Panel VAR model}

Before GMM based panel VAR model, we conduct LLC and IPS panel unit root test which are reported in Table 14. The tests suggest that all panel variables are stationary. In GMM based panel models given in Table 15, all variables are in their first lags, i.e., t-1. For all panel regression models, INT, INF and GAP variables have positive and significant impact on current INT variable. Coefficient for open economy variable, i.e., XR, is observed to be positive and significant as given in regression (1). All relevant institutional variables, namely as REGQUA, POLSTAB and GOVEFF are observed to have negative and significant impact on current INT, suggesting the contributing impact of credibility on domestic institutions. Last but not least, dummy variables suggest consistent results according to the literature. IT dummy has positive impact suggesting the pressure to increase interest rate to maintain price stability, whereas crisis dummy has negative impact suggesting the need to revive economy in the times of economic crisis. The relevant IRFs are given in Figures 10 and 11. Moreover, Table 16 and 17 suggest that INT itself compose the highest weight in the variance of INT in the short run as GMM is a dynamic analysis in both model 1 (including XR) and 2 (including GOV). However, the impact declines abruptly as horizon increases. It is further observed that REGQUA is of first importance in the variation of INT after itself with a proportion of around $28 \%$ in horizon 8.

The empirical findings obtained from panel VAR model for 11 emerging countries are consistent to Taylor rule model. Since the model is based on GMM methodology, it will provide dynamic, i.e., short run, results. Interest rate is observed to be significantly affected from its lagged value suggesting a smoothing effect as mentioned in the literature. The positive impact 
of inflation, output gap and exchange rate is consistent to the literature in the way that a rise in inflation rate, a higher actual output than the potential level and a depreciation in the domestic currency push short term domestic nominal interest rates upwards. Adoption of IT policy generally suggests a significant and immediate intervention to inflation via interest rates. Hence a positive impact of IT adoption dummy explains the immediate intervention in the short run. Negative sign of economic crisis dummy is attributed to the desire of central banks to revive/cool down the economy when there is a crisis/boom. In variance decompositions, interest rate compose the highest contribution to the variance of interest rate in both models. Model 1 that includes exchange rate suggests that the inflation explains the highest variation following interest rate in the short horizon but exchange rate dominates in the longer horizon. Model 2 that includes governance indicators suggest that following interest rate, regulation quality dominates significantly in both short and long horizons.

\section{Conclusion}

Contributions of IT policy are known globally and both developed and developing countries implement this policy as the main central bank monetary policy rule. Maintaining price stability is also critically crucial for emerging countries together with the financial fragility of these economies. Moreover, credibility to domestic institutions such as central bank and the government seems to be of high importance as the portfolio inflows are generally determined by such credibility issues. Emerging economies have high growth potential but are generally in need of investment which hampers the capacity to use this potential. These economies attract portfolio investments via relatively higher interest rates. Hence, in the determination of interest rate, open economy issues related to portfolio inflows should be considered for emerging countries. It may be argued that credibility and capital inflows work in favor of the central bank. In order to reflect credibility and capital inflows, institutional variables and exchange rate seem to be relevant indicators. This study examines Taylor rule for emerging countries including exchange rate and institutional variables using several methodologies.

Turkish economy is at the heart of this study. Moreover, a panel of 11 IT emerging economies is examined. For time series analysis for Turkey, SVAR model is used and the IRFs and variance decompositions are observed. Empirical models for Turkey suggest that in the short run models, interest rate itself is the main contributor to the variation in the interest rate; whereas, in the long run models, output gap and the institutional variable (regulation quality) are observed to be the main contributors to interest rate. 
Two different models for SVAR both in long and short run suggest that the inflation is not the primary variable to explain the variation in short term interest rate. Put it differently, we cannot mention about a full-commitment to IT policy for Turkey not only in the short run but also in the long run in the way that inflation should be the key objectives of the monetary authority. Bernanke and Mishkin (1997) discuss that IT policy is not an ironclad policy rule but rather flexible such that allows even for discretionary monetary policy to accommodate the economy to supply shocks such as oil price shocks. However, they further argue that such a flexibility is possible for short term targets or there can be an "escape clause" that IT is suspended for some period in the times of adverse economic environment. According to Bernanke and Mishkin (1997, p.100) "the rationale for treating inflation as the primary goal of monetary policy is clearly strongest when medium- to long-term horizons are considered". Moving from this argument, checking longer horizons for variance decompositions for Turkey, we observe that for model 2 , including regulation quality, the weight of inflation becomes the highest following the weight of interest rate itself after horizon 4 which suggests commitment to IT for this model. Nevertheless, short run results for model 1 reflect that inflation comes after exchange rate as the determinant of the interest rate even in higher horizons. GMM based Panel VAR model—which is a dynamic, i.e., short run model—for 11 emerging countries (including Turkey) suggests that interest rate itself and institutional variable contribute most to the variation in interest rate. Furthermore, all regression models suggest that IT lowers and economic crisis push interest rate upwards.

In conclusion, both time series and panel data models suggest the significance of institutional variables on the determination of interest rate. This may be attributed to the importance of credibility for emerging markets and that lack of credibility creates a further burden on nominal interest rates. For further study, the rest of the emerging economies can be examined individually using SVAR model and the panel dataset of emerging countries may include a regional dummy so as to control for any regional differences. 


\section{$\underline{\text { References }}$}

Arellano, M., Bover, O., 1995. Another look at the instrumental variable estimation of errorcomponents models. Journal of Econometrics 68 (1), 29-51.

Bai and Perron, 2003. "Computation and Analysis of Multiple Structural Change Models," Journal of Applied Econometrics, 6, 72-78.

Bernanke, B. S., and Mishkin, F. S. (1997). Inflation targeting: a new framework for monetary policy?, National Bureau of Economic Research, No. w5893.

Bernanke, B. S. (1986). Alternative explanations of the money-income correlation. NBER

Working Paper. No. 1842. http://www.nber.org/papers/w1842.pdf

Blanchard, O. J., and Quah, D. (1988). The dynamic effects of aggregate demand and supply disturbances. National Bureau of Economic Research, No. w2737.

Blanchard, O. J. and M. W.Watson. (1986). Are business cycles all alike?. R.J. Gordon

(Ed.) American business cycle: Continuity and change: University of Chicago

Press, 1986, 123-180.

Brito, R. D., \& Bystedt, B. (2010). Inflation targeting in emerging economies: Panel evidence. Journal of Development Economics, 91, 198-210.

Fraga, A., I. Goldfajn, and A. Minella. 2003. Inflation Targeting in Emerging Market Economies. NBER Working Paper Series 10019.

Frömmel, M., Garabedian, G., \& Schobert, F., 2011. "Monetary policy rules in Central and Eastern European Countries: Does the exchange rate matter?", Journal of Macroeconomics, 33(4), pp. 807-818.

Holtz-Eakin, D., Newey, W.K., Rosen, H.S., 1988. Estimating vector autoregressions with panel data. Econometrica 56, 1371-1395.

Im, K. S., Pesaran, M. H., \& Shin, Y., 2003. Testing for unit roots in heterogeneous panels. Journal of econometrics, 115(1), 53-74.

Kaufmann, Daniel, Kraay, Aart, and Mastruzzi, Massimo, 2010. "The Worldwide Governance Indicators Methodology and Analytical Issues", The World Bank Policy Research Working Paper No. 5430.

Keating, J.W. (1992). Structural Approaches to Vector Autoregressions. Federal Reserve

Bank of St. Louis Review. September/October.

http://research.stlouisfed.org/publications/review/92/09/Vector_Sep_Oct1992.pdf

Levin, A., Lin, C. F., \& Chu, C. S. J., 2002. Unit root tests in panel data: asymptotic and finite-sample properties. Journal of econometrics, 108(1), 1-24. 
Lin, S., Ye, H., 2009. Does inflation targeting make a difference in developing countries? Journal of Development Economics 89 :118-123.

Love, I., Zicchino, L., 2006. Financial development and dynamic investment behavior: evidence from panel VAR. The Quarterly Review of Economics and Finance 46 (2), $190-210$.

Mishkin, F.S. 2004. Can Inflation Targeting Work in Emerging Market Countries? NBER Working Paper Series 10646.

Sánchez-Fung, José R., 2011. "Estimating monetary policy reaction functions for emerging market economies: The case of Brazil”, Economic Modelling, Vol. 28, p.1730-1738.

Shapiro, M., and Watson, M. (1988). Sources of business cycles fluctuations, NBER Macroeconomics Annual, Vol. 3, pp. 111-156.

Sims, C.A. (1986). Are Forecasting Models Usable for Policy Analysis. Quarterly Review of the Federal Reserve Bank of Minneapolis, Winter, 2-16.

Siregar, R., and S. Goo. 2008. Inflation Targeting Policy: The Experiences of Indonesia and Thailand. CAMA (Centre for Applied Macroeconomic Analysis in the Australian National University) Working Paper 23.

Taylor, J. B. (1993). Discretion versus Policy Rules in Practice. Carnegie-Rochester Conference Series on Public Policy (December), pp. 195-214.

Teles, V. K., and Zaidan, M., 2010. “Taylor principle and inflation stability in emerging market countries", Journal of Development Economics, 91(1), pp. 180-183.

Walsh, Carl E., 2009. “Inflation Targeting: What Have We Learned?”, International Finance, 12:2, pp. 195-233. 
Appendix A: Time Series SVAR Model - Turkey - 2003Q1 2014Q4

Table 3: Unit Root Tests

\begin{tabular}{|c|c|c|}
\hline Variables & ADF & PP \\
\hline \multirow{2}{*}{ INT } & -5.756177 & -4.824462 \\
& $(0.0000)$ & $(0.0003)$ \\
\hline \multirow{2}{*}{ INF } & -4.523087 & -8.059794 \\
& $(0.0007)$ & $(0.0000)$ \\
\hline \multirow{2}{*}{ GAP } & -3.273332 & -7.974226 \\
& $(0.0225)$ & $(0.0000)$ \\
\hline \multirow{2}{*}{ D(XR) } & -0.281517 & -0.281517 \\
& $(0.9197)$ & $(0.9197)$ \\
\hline \multirow{2}{*}{ REGQUA } & -6.605655 & $(0.0000)$ \\
\hline \multirow{2}{*}{ D(REGQUA) } & $(0.0000)$ & -7.070321 \\
& -1.990000 & $(0.0000)$ \\
\hline
\end{tabular}

Note: Augmented Dickey Fuller (ADF) test with constant. Maximum lag is selected as 9 and optimal lag selection is based on Schwarz information criteria. Phillips-Perron (PP) test with constant. Spectral estimation method is Bartlett kernel and automatic bandwidth selection is Newey-West. 
Table 4: Short Run SVAR for Model 1

\begin{tabular}{lcccc}
\hline & Coefficient & Std. Error & z-Statistic & Prob. \\
\hline $\mathrm{C}(2)$ & -0.377221 & 0.240845 & -1.566237 & 0.1173 \\
$\mathrm{C}(4)$ & -0.061377 & 0.037647 & -1.630332 & 0.1030 \\
$\mathrm{C}(5)$ & 0.001093 & 0.022691 & 0.048169 & 0.9616 \\
$\mathbf{C}(7)$ & $\mathbf{0 . 1 6 8 6 6 5}$ & $\mathbf{0 . 0 4 9 5 5 6}$ & $\mathbf{3 . 4 0 3 5 0 6}$ & $\mathbf{0 . 0 0 0 7}$ \\
$\mathbf{C}(\mathbf{8})$ & $\mathbf{0 . 0 7 8 9 8 1}$ & $\mathbf{0 . 0 2 9 0 2 5}$ & $\mathbf{2 . 7 2 1 0 9 6}$ & $\mathbf{0 . 0 0 6 5}$ \\
$\mathbf{C}(\mathbf{9})$ & $\mathbf{0 . 2 9 5 8 4 4}$ & $\mathbf{0 . 1 9 0 6 7 9}$ & $\mathbf{1 . 5 5 1 5 2 5}$ & $\mathbf{0 . 1 2 0 8}$ \\
$\mathrm{C}(1)$ & 0.039460 & 0.004159 & 9.486833 & 0.0000 \\
$\mathrm{C}(3)$ & 0.063753 & 0.006720 & 9.486833 & 0.0000 \\
$\mathrm{C}(6)$ & 0.009704 & 0.001023 & 9.486833 & 0.0000 \\
$\mathrm{C}(10)$ & 0.012413 & 0.001308 & 9.486833 & 0.0000 \\
\hline
\end{tabular}

Note: Model 1 includes output gap, exchange rate, inflation rate and interest rate. VAR model includes 2 lags after specifying the optimum lag according to Schwarz information criteria.. Log likelihood of the SVAR model is 420.0159 .

Table 5: Variance Decomposition for Model 1 (Short Run)

\begin{tabular}{ccccc}
\hline Horizon & GAP & XR & INF & INT \\
\hline 1 & 10.75570 & 12.14179 & 3.915087 & 73.18742 \\
2 & 9.010850 & 13.06209 & 2.704715 & 75.22235 \\
4 & 7.035852 & 17.73141 & 1.440718 & 73.79202 \\
6 & 7.728231 & 19.02421 & 1.078778 & 72.16878 \\
8 & 7.287581 & 19.66714 & 0.911236 & 72.13405 \\
12 & 7.312217 & 20.30443 & 0.719261 & 71.66409 \\
18 & 7.368948 & 20.70272 & 0.598019 & 71.33031 \\
\hline
\end{tabular}

Note: Structural Factorization. 
Figure 2: Responses of interest rate to structural shocks for Model 1 (Short Run SVAR)

Response to Structural One S.D. Innovations \pm 2 S.E.

Response of INT to GAP Shock

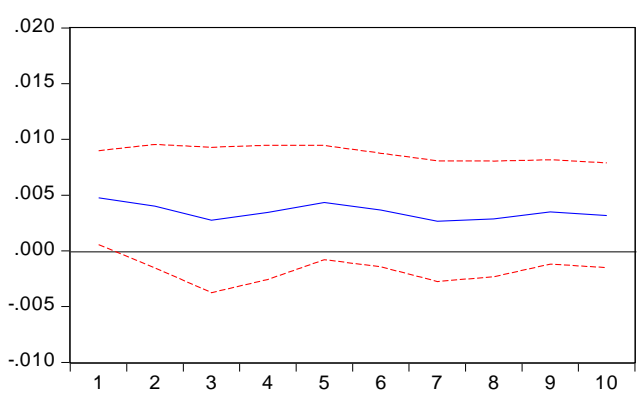

Response of INT to INF Shock

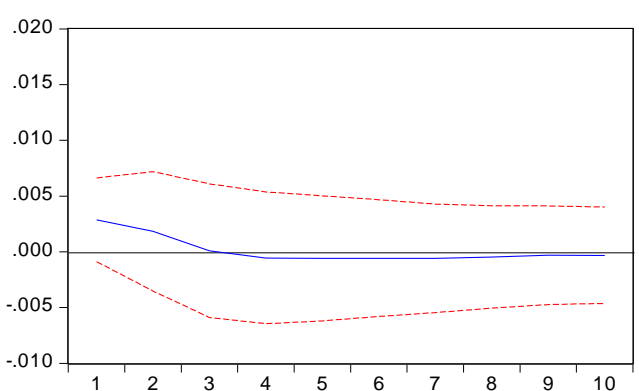

Response of INT to XR Shock

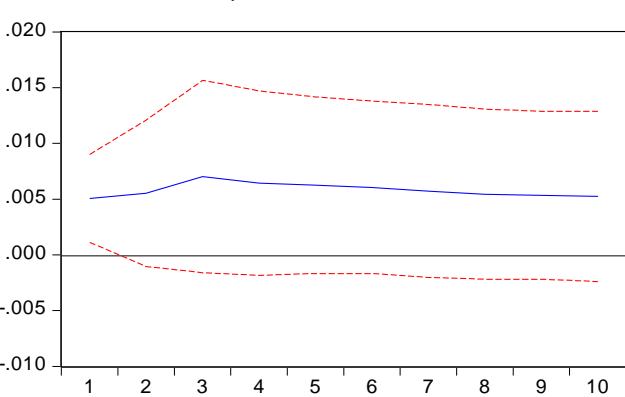

Response of INT to INT Shock

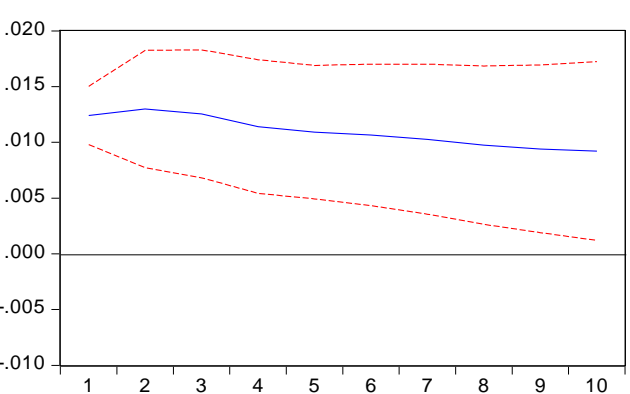

Figure 3: Historical Decomposition of Interest Rate Model 1 (Short Run)

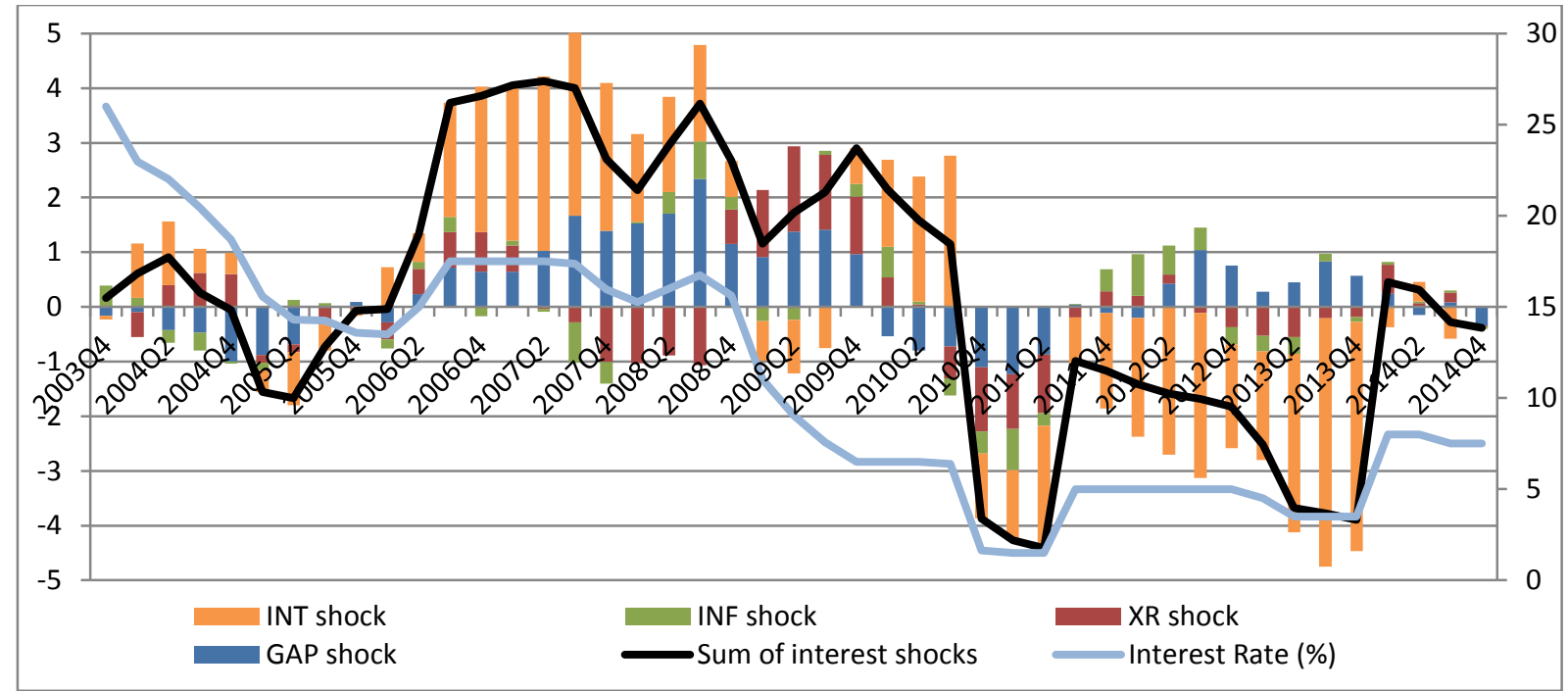


Table 6: Long run SVAR for Model 1

\begin{tabular}{ccccc}
\hline & Coefficient & Std. Error & z-Statistic & Prob. \\
\hline C $(1)$ & 0.088218 & 0.009299 & 9.486833 & 0.0000 \\
C (2) & -0.034524 & 0.009017 & -3.828653 & 0.0001 \\
C(3) & 0.061459 & 0.008140 & 7.550186 & 0.0000 \\
$\mathbf{C}(\mathbf{4})$ & $\mathbf{0 . 4 0 6 6 2 5}$ & $\mathbf{0 . 0 4 6 6 7 3}$ & $\mathbf{8 . 7 1 2 1 2 2}$ & $\mathbf{0 . 0 0 0 0}$ \\
C(5) & 0.055344 & 0.005834 & 9.486833 & 0.0000 \\
C(6) & 0.008039 & 0.004855 & 1.655790 & 0.0978 \\
C(7) & $\mathbf{0 . 0 3 1 5 5 1}$ & $\mathbf{0 . 0 1 8 1 7 1}$ & $\mathbf{1 . 7 3 6 3 0 8}$ & $\mathbf{0 . 0 8 2 5}$ \\
C(8) & 0.032070 & 0.003380 & 9.486833 & 0.0000 \\
C(9) & $\mathbf{0 . 1 0 6 7 1 3}$ & $\mathbf{0 . 0 1 3 8 7 8}$ & $\mathbf{7 . 6 8 9 2 0 6}$ & $\mathbf{0 . 0 0 0 0}$ \\
C(10) & 0.054530 & 0.005748 & 9.486833 & 0.0000 \\
\hline
\end{tabular}

Note: Same notes as in Table 3.

Table 7: Variance Decomposition for Model 1 (Long Run)

\begin{tabular}{ccccc}
\hline Horizon & GAP & XR & INF & INT \\
\hline 1 & 85.26082 & 0.187377 & 14.20067 & 0.351134 \\
2 & 85.84076 & 0.109408 & 13.81022 & 0.239619 \\
4 & 87.07524 & 0.472780 & 11.13552 & 1.316463 \\
6 & 89.03983 & 0.502262 & 9.138073 & 1.319835 \\
8 & 89.19813 & 0.546503 & 8.638524 & 1.616839 \\
12 & 89.81658 & 0.573336 & 7.936406 & 1.673682 \\
18 & 90.26947 & 0.587170 & 7.456180 & 1.687179
\end{tabular}

Note: Same notes as in Table 4. 
Figure 4: Responses of interest rate to structural shocks for Model 1 (Long Run SVAR) Response to Structural One S.D. Innovations

Figure 5: Historical Decomposition of Interest Rate for Model 1 (Long Run)

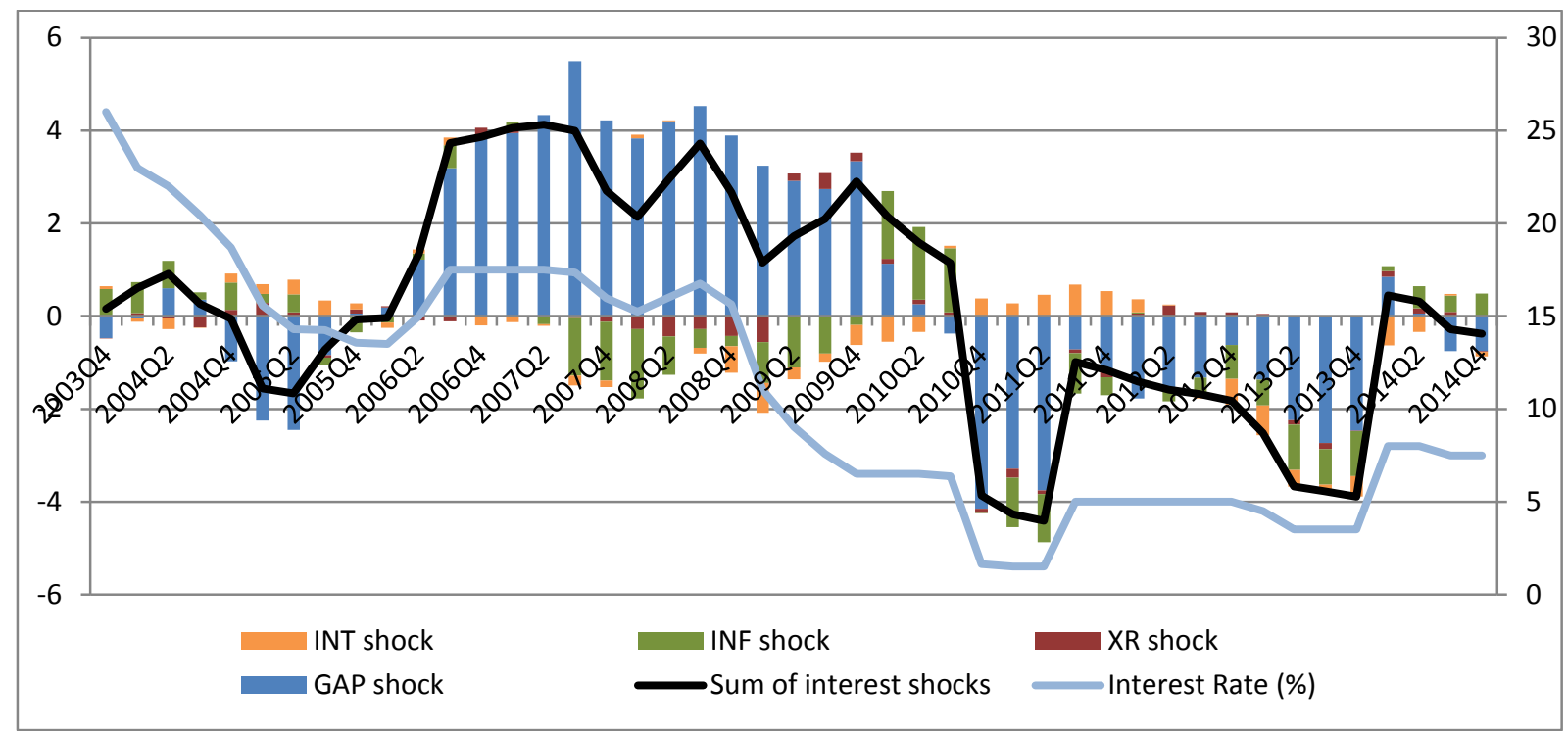

Table 8: Short Run SVAR for Model 2

\begin{tabular}{lcccc}
\hline & Coefficient & Std. Error & z-Statistic & Prob. \\
\hline C $(2)$ & 0.353660 & 0.127403 & 2.775919 & 0.0055 \\
$\mathrm{C}(4)$ & -0.007318 & 0.044500 & -0.164449 & 0.8694 \\
$\mathrm{C}(5)$ & -0.111245 & 0.047662 & -2.334035 & 0.0196 \\
$\mathbf{C}(\mathbf{7})$ & $\mathbf{0 . 1 2 2 4 8 7}$ & $\mathbf{0 . 0 6 1 3 8 0}$ & $\mathbf{1 . 9 9 5 5 4 9}$ & $\mathbf{0 . 0 4 6 0}$ \\
$\mathbf{C}(\mathbf{8})$ & $\mathbf{- 0 . 0 8 0 7 9 6}$ & $\mathbf{0 . 0 6 9 5 0 5}$ & $\mathbf{- 1 . 1 6 2 4 5 4}$ & $\mathbf{0 . 2 4 5 1}$ \\
$\mathbf{C}(\mathbf{9})$ & $\mathbf{- 0 . 0 4 4 5 7 1}$ & $\mathbf{0 . 2 0 3 3 0 9}$ & $\mathbf{- 0 . 2 1 9 2 3 0}$ & $\mathbf{0 . 8 2 6 5}$ \\
$\mathrm{C}(1)$ & 0.036561 & 0.003812 & 9.591663 & 0.0000 \\
$\mathrm{C}(3)$ & 0.031592 & 0.003294 & 9.591663 & 0.0000 \\
$\mathrm{C}(6)$ & 0.010212 & 0.001065 & 9.591663 & 0.0000 \\
$\mathrm{C}(10)$ & 0.014082 & 0.001468 & 9.591663 & 0.0000
\end{tabular}

Note: Model 1 includes output gap, regulation quality, inflation rate and interest rate. VAR model includes 3 lags after specifying the optimum lag according to Schwarz information criteria.. Log likelihood of the SVAR model is 457.0052 . 
Table 9: Variance Decomposition for Model 2 (Short Run)

\begin{tabular}{ccccc}
\hline Horizon & GAP & REGQUA & INF & INT \\
\hline 1 & 5.687413 & 2.650500 & 0.095671 & 91.56642 \\
2 & 4.804108 & 1.967793 & 1.648736 & 91.57936 \\
4 & 5.762712 & 1.285345 & 7.722437 & 85.22951 \\
6 & 7.576078 & 1.507734 & 11.11589 & 79.80030 \\
8 & 7.799263 & 1.728468 & 12.58267 & 77.88960 \\
12 & 8.352683 & 1.852458 & 13.58587 & 76.20899 \\
18 & 8.686983 & 1.915519 & 14.08848 & 75.30901
\end{tabular}

Note: Same notes as in Table 4.

Figure 6: Responses of interest rate to structural shocks for Model 2 (Short Run SVAR) Response to Structural One S.D. Innovations \pm 2 S.E.
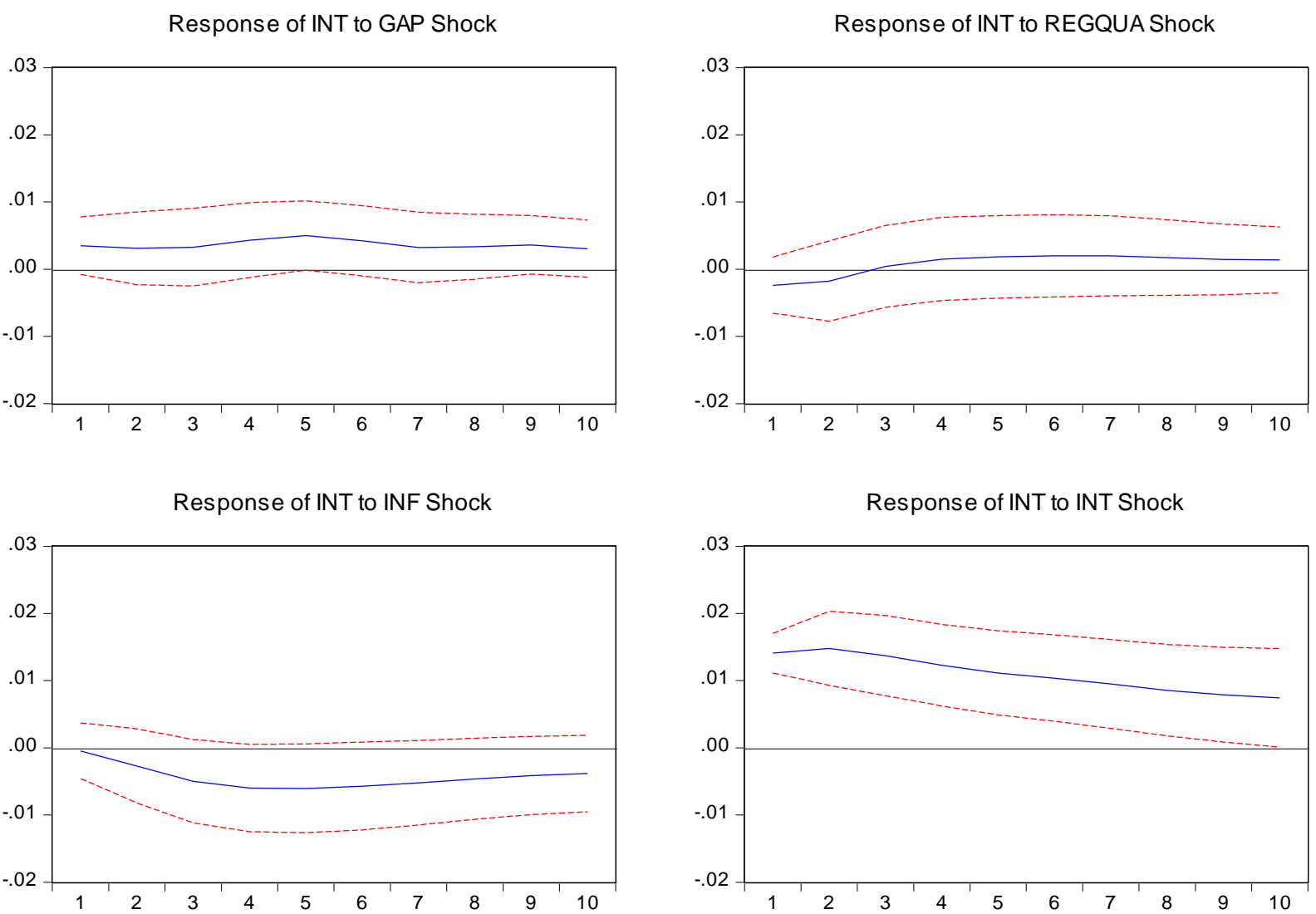
Figure 7: Historical Decomposition of Interest Rate Model 2 (Short Run)

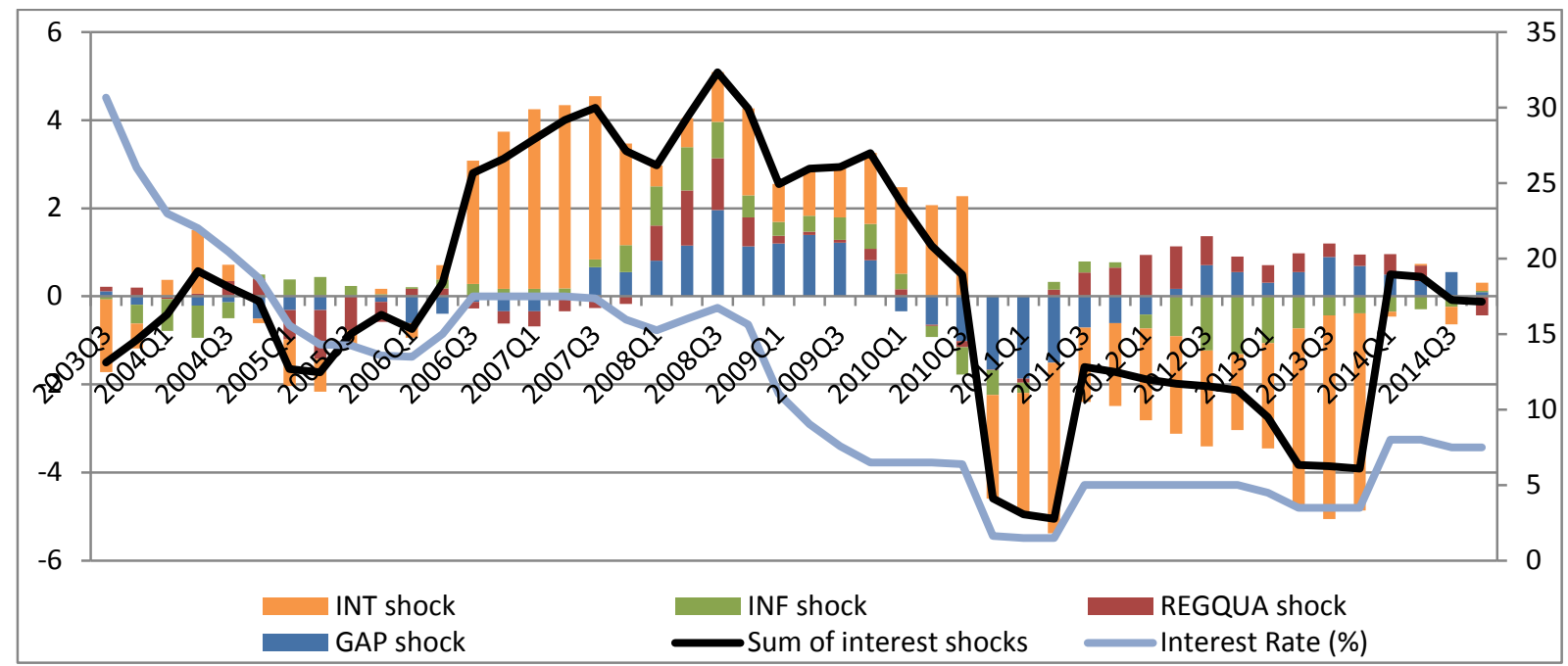

Table 10: Long run SVAR for Model 2

\begin{tabular}{lrrrc}
\hline & Coefficient & Std. Error & z-Statistic & Prob. \\
\hline C(1) & 0.048703 & 0.005078 & 9.591663 & 0.0000 \\
C(2) & -0.061593 & 0.017613 & -3.496978 & 0.0005 \\
C(3) & 0.020908 & 0.005356 & 3.903743 & 0.0001 \\
$\mathbf{C}(4)$ & 0.184468 & 0.026759 & 6.893633 & 0.0000 \\
C(5) & 0.111237 & 0.011597 & 9.591663 & 0.0000 \\
C(6) & -0.025240 & 0.004124 & -6.119804 & 0.0000 \\
C(7) & -0.115742 & 0.014162 & -8.172626 & 0.0000 \\
C(8) & 0.021539 & 0.002246 & 9.591663 & 0.0000 \\
C(9) & 0.018540 & 0.007157 & 2.590526 & 0.0096 \\
C(10) & 0.046736 & 0.004873 & 9.591663 & 0.0000 \\
\hline
\end{tabular}

Note: Same notes as in Table 7. 
Topics in Middle Eastern and African Economies

Vol. 18, Issue No. 1, May 2016

Table 11: Variance Decomposition for Model 2 (Long Run)

\begin{tabular}{ccccc}
\hline Horizon & GAP & REGQUA & INF & INT \\
\hline 1 & 35.58345 & 55.13768 & 6.337408 & 2.941466 \\
2 & 38.26665 & 54.80423 & 5.226944 & 1.702172 \\
4 & 52.11137 & 41.04845 & 4.043350 & 2.796829 \\
6 & 62.47979 & 32.02403 & 3.184672 & 2.311514 \\
8 & 66.65985 & 27.85549 & 2.977382 & 2.507284 \\
12 & 72.01299 & 23.00954 & 2.529683 & 2.447789 \\
18 & 75.73190 & 19.77521 & 2.204223 & 2.288663 \\
\hline
\end{tabular}

Note: Same notes as in Table 4. 
Figure 8: Responses of interest rate to structural shocks for Model 2 (Long Run SVAR) Response to Structural One S.D. Innovations

Response of INT to GAP Shock

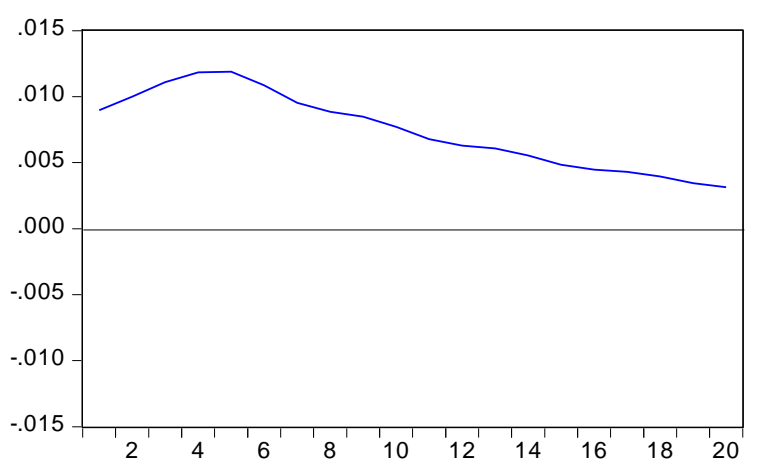

Response of INT to INF Shock



Response of INT to REGQUA Shock

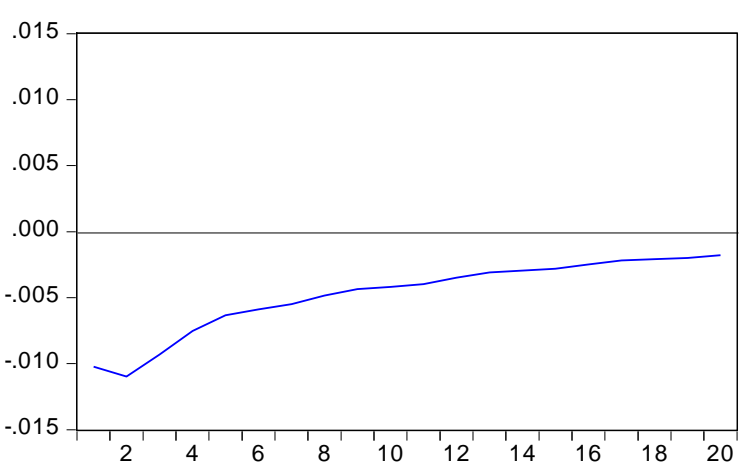

Response of INT to INT Shock

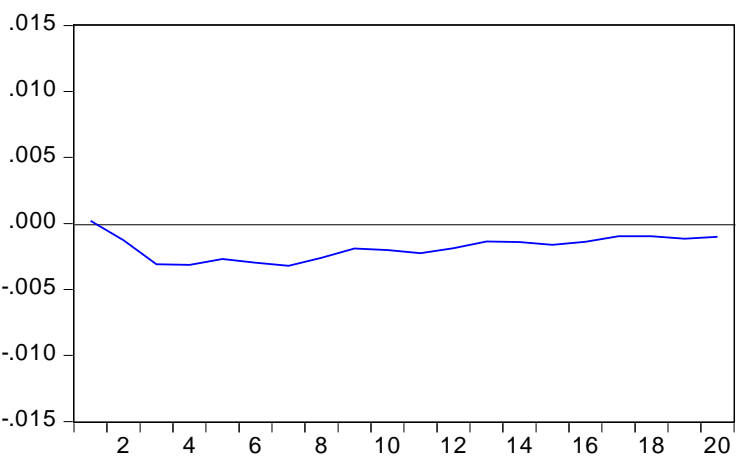

Figure 9: Historical Decomposition of Interest Rate Model 2 (Long Run)

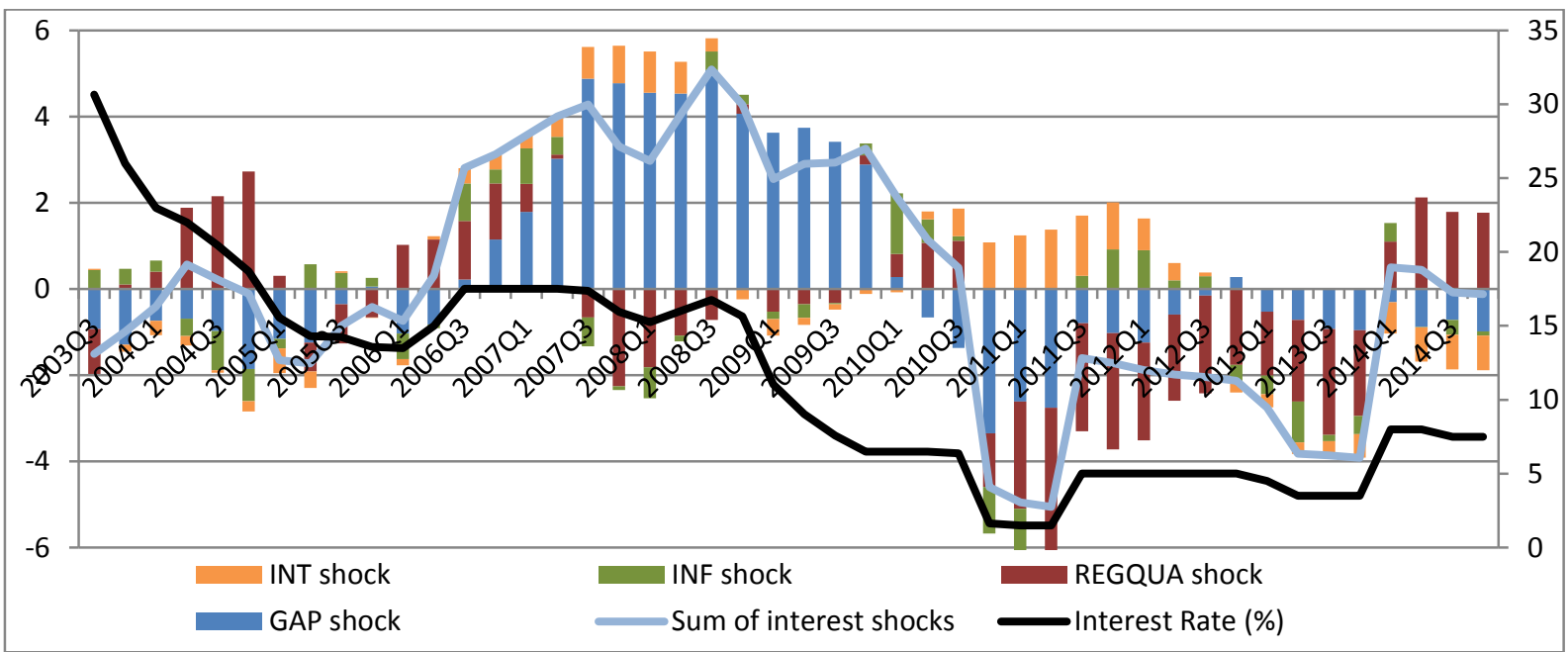


Table 12: Inflation Targets and Realizations

\begin{tabular}{ccc}
\hline Years & Target & Realization \\
\hline 2002 & 35 & 29.7 \\
2003 & 20 & 18.4 \\
2004 & 12 & 9.3 \\
2005 & 8 & 7.7 \\
2006 & 5 & 9.7 \\
2007 & 4 & 8.4 \\
2008 & 4 & 10.1 \\
2009 & 7.5 & 6.5 \\
2010 & 6.5 & 6.4 \\
2011 & 5.5 & 10.4 \\
2012 & 5 & 6.2 \\
2013 & 5 & 7.4 \\
2014 & 5 & 8.2
\end{tabular}

Note: Year-end inflation rates calculated as the 12-month change in the CPI are set as the target variable. 
Table 13: Bai-Perron tests of Multiple breakpoint tests

Breakpoint variables: INF

Non-breakpoint variables: GAP XR REGQUA CRISISDUMMY TARGETDUMMY C

Bai-Perron tests of $L+1$ vs. $L$ sequentially determined breaks

$\begin{array}{lccc}\text { Break Test } & \text { F-statistic } & \text { Scaled F-statistic } & \text { Critical Value** } \\ 0 \text { vs. } 1 * & 41.47028 & 41.47028 & 8.58 \\ 1 \text { vs. } 2 & 1.130432 & 1.130432 & 10.13\end{array}$

Break Dates: $\quad$ Sequential: 2010Q1 Repartition: 2010Q1

Bai-Perron tests of 1 to $\mathrm{M}$ globally determined breaks

$\begin{array}{ccccc}\text { Breaks } & \begin{array}{c}\text { UDMax } \\ \text { statistic* }^{*}\end{array} & \begin{array}{c}\text { WDMax } \\ \text { statistic* }\end{array} & \begin{array}{c}\text { UDMax } \\ \text { critical value*** }\end{array} & \begin{array}{c}\text { WDMax } \\ \text { critical value** }^{* *}\end{array} \\ 1 & 41.47028 & 41.47028 & 8.88 & 9.91\end{array}$

Estimated break dates:

2010Q

Note: Break test options: Trimming 0.15, No of maximum break is 2 for sequentially determined breaks and 1 for globally determined breaks. Test statistics employ HAC covariances (Prewhitening with lags $=1$, Quadratic-Spectral kernel, Andrews bandwidth). (*) denotes significance at the 0.05 level. (**) denotes Bai-Perron (2003) critical values. 


\section{Appendix B: Panel VAR Model}

Table 14: Panel Unit Root Test

\begin{tabular}{|c|c|c|}
\hline & IPS & LLC \\
\hline \multirow{2}{*}{ INT } & $-5.72632^{* *}$ & $-13.9949^{* *}$ \\
& $(0.0000)$ & $(0.0000)$ \\
\hline \multirow{2}{*}{ GNF } & $-3.07029^{* *}$ & $-3.24781^{* *}$ \\
& $(0.0011)$ & $(0.0006)$ \\
\hline \multirow{2}{*}{ XR } & $-5.34441^{* *}$ & $-8.72870^{* *}$ \\
& $(0.0000)$ & $(0.0000)$ \\
\hline \multirow{2}{*}{ REGQUA } & $-5.68896^{* * *}$ & $-6.59089^{* *}$ \\
& $(0.0000)$ & $(0.0000)$ \\
\hline \multirow{2}{*}{ POLSTAB } & $-1.74416^{* *}$ & $(0.0002)$ \\
\hline \multirow{2}{*}{ GOVEFF } & $(0.0406)$ & $-4.91635^{* *}$ \\
& $-2.13001^{* *}$ & $(0.0000)$ \\
\hline
\end{tabular}

Note: Automatic lag length selection based on SIC with maximum lag length of 3. Newey-West automatic bandwidth selection and Bartlett kernel is used. Tests include individual intercept and trend. Values in parentheses are p-values. $(*)$ and $(* *)$ suggest significance at 5 and $10 \%$ significance levels. 
Table 15: Panel vector autoregresssion (GMM Estimation)

\begin{tabular}{|c|c|c|c|c|c|}
\hline VARIABLES & (1) & (2) & (3) & (4) & (5) \\
\hline \multicolumn{6}{|l|}{ Taylor Rule } \\
\hline \multirow[t]{2}{*}{$\mathrm{INT}_{t-1}$} & $0.326 * *$ & $0.246^{*}$ & $0.389 * *$ & $0.289 * *$ & $0.479 * *$ \\
\hline & $(0.034)$ & $(0.044)$ & $(0.0786)$ & $(0.097)$ & $(0.025)$ \\
\hline \multirow[t]{2}{*}{$\mathrm{INF}_{t-1}$} & $0.501 * *$ & $0.705^{*}$ & $0.410^{*}$ & $0.667 * *$ & $0.291 * *$ \\
\hline & $(0.054)$ & $(0.069)$ & $(0.102)$ & $(0.119)$ & $(0.029)$ \\
\hline \multirow[t]{2}{*}{$\mathbf{G A P}_{t-1}$} & $0.707 * *$ & $0.866^{*}$ & $1.218^{*}$ & $0.686^{* *}$ & $0.132 * *$ \\
\hline & $(0.108)$ & $(0.129)$ & $(0.19)$ & (0.189) & $(0.055)$ \\
\hline \multicolumn{6}{|l|}{ Open Economy } \\
\hline \multirow[t]{2}{*}{$\mathbf{X R}_{t-1}$} & $0.115^{* *}$ & & & & $0.050 * *$ \\
\hline & $(0.027)$ & & & & $(0.009)$ \\
\hline \multicolumn{6}{|l|}{ Institutional Var. } \\
\hline \multirow[t]{2}{*}{ REGQUA $_{t-1}$} & & $-0.209 * *$ & & & \\
\hline & & $(0.034)$ & & & \\
\hline \multirow[t]{2}{*}{ POLSTAB $_{t-1}$} & & & $-0.0729 * *$ & & $-0.079 * *$ \\
\hline & & & $(0.0216)$ & & $(0.005)$ \\
\hline \multirow[t]{2}{*}{ GOVEFF $_{t-1}$} & & & & $-0.633 * *$ & \\
\hline & & & & $(0.155)$ & \\
\hline \multicolumn{6}{|l|}{ Dummy Var. } \\
\hline \multirow[t]{2}{*}{$\mathbf{D}_{\text {crisis }}$} & $-0.068 * *$ & $-0.075^{* *}$ & $-0.112 * *$ & $-0.088 * *$ & $-0.072 * *$ \\
\hline & $(0.013)$ & $(0.011)$ & $(0.015)$ & $(0.017)$ & $(0.011)$ \\
\hline \multirow[t]{2}{*}{$\mathrm{D}_{\text {target }}$} & $0.012^{*}$ & $0.049 * *$ & 0.00149 & $0.158 * *$ & $0.085^{* *}$ \\
\hline & $(0.007)$ & $(0.015)$ & $(0.0124)$ & $(0.031)$ & $(0.006)$ \\
\hline Obs. & 143 & 143 & 143 & 143 & 143 \\
\hline
\end{tabular}

Note: Values in parentheses indicate standard deviations. Left-hand-side variable is interest rate $\left(\mathrm{INT}_{t}\right)$. Optimal lag=1 from Schwarz Info Criteria out of maximum lag of 3. Number of instruments is selected as 5. $(*)$ and $(* *)$ indicate significance at $10 \%$ and $5 \%$ successively. 
Table 16: Forecast-error variance decomposition for Panel VAR for Model 1

\begin{tabular}{ccccc}
\hline Horizon & INT & INF & GAP & XR \\
\hline 1 & 100 & 0 & 0 & 0 \\
2 & 82.47014 & 9.75353 & 1.63472 & 6.14162 \\
3 & 74.01021 & 12.61596 & 2.89129 & 10.48254 \\
4 & 69.87404 & 13.21848 & 3.83582 & 13.07167 \\
5 & 67.64904 & 13.20894 & 4.61943 & 14.52259 \\
6 & 66.31898 & 13.04626 & 5.35047 & 15.28429 \\
7 & 65.38774 & 12.85031 & 6.12007 & 15.64188 \\
8 & 64.57736 & 12.64057 & 7.0246 & 15.75745 \\
9 & 63.70209 & 12.40413 & 8.18453 & 15.70926 \\
10 & 62.60399 & 12.11439 & 9.76105 & 15.52057 \\
\hline
\end{tabular}

Figure 10: Responses of interest rate to structural shocks for Model 1
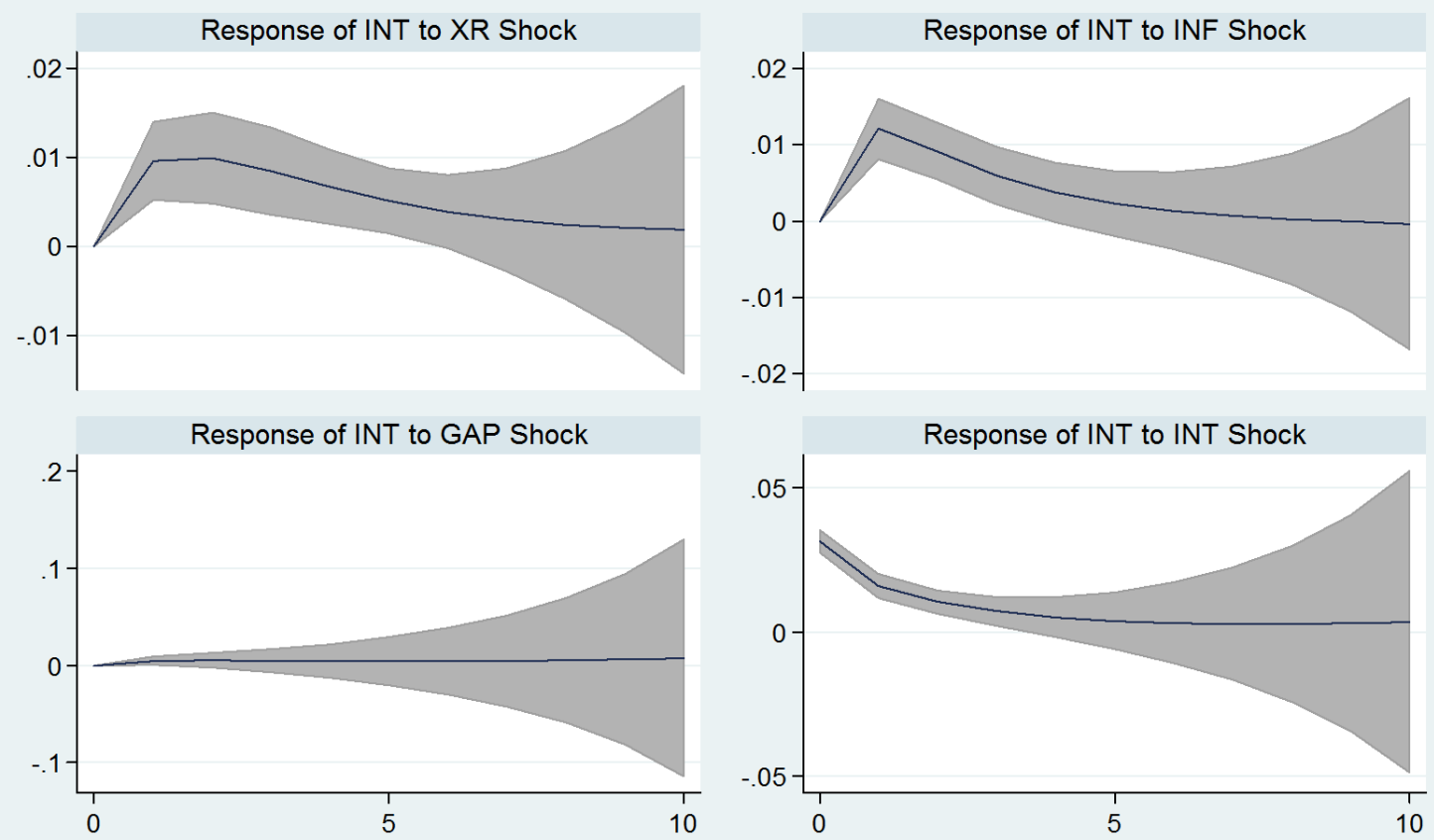

step 
Table 17: Forecast-error variance decomposition for Panel VAR for Model 2

\begin{tabular}{|c|c|c|c|c|c|}
\hline \multicolumn{2}{|r|}{ Horizon } & INT & INF & GAP & REGQUA \\
\hline \multicolumn{2}{|r|}{1} & 100 & 0 & 0 & 0 \\
\hline \multicolumn{2}{|r|}{2} & 76.82929 & 5.71077 & 4.26825 & 13.19168 \\
\hline \multicolumn{2}{|r|}{3} & 65.36974 & 8.61762 & 5.66473 & 20.34791 \\
\hline \multicolumn{2}{|r|}{4} & 59.59732 & 10.26761 & 5.94807 & 24.187 \\
\hline \multicolumn{2}{|r|}{5} & 56.39178 & 11.36831 & 5.88856 & 26.35135 \\
\hline \multicolumn{2}{|r|}{6} & 54.50808 & 12.16228 & 5.74942 & 27.58023 \\
\hline \multicolumn{2}{|r|}{7} & 53.3691 & 12.74762 & 5.61766 & 28.26562 \\
\hline \multicolumn{2}{|r|}{8} & 52.67035 & 13.17645 & 5.51588 & 28.63732 \\
\hline 9 & 52.23773 & 13.48504 & 5.44402 & 28.83321 & \\
\hline 10 & 51.96742 & 13.70251 & 5.39573 & 28.93433 & \\
\hline
\end{tabular}

Figure 11: Responses of interest rate to structural shocks for Model 2

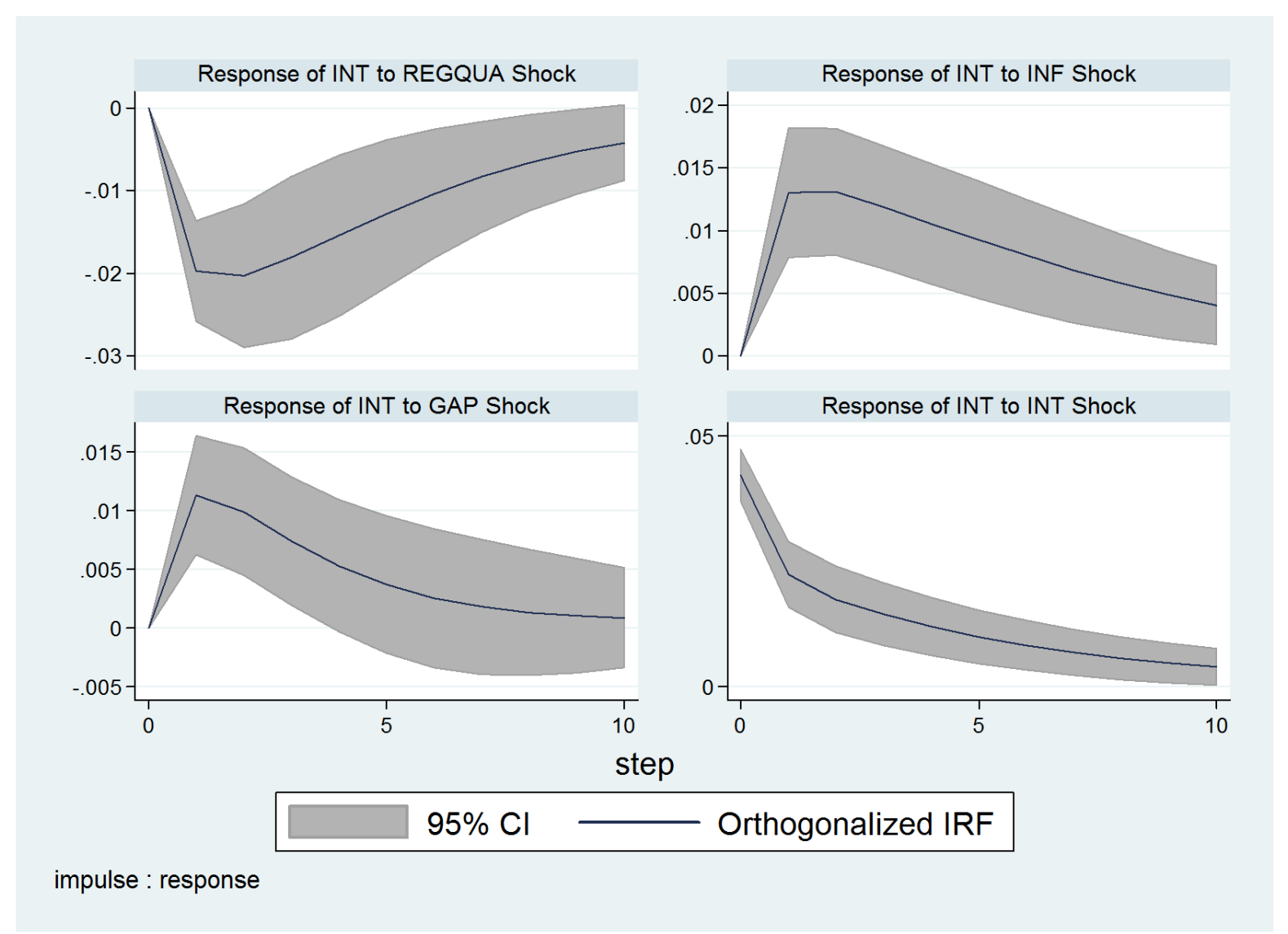

